\title{
A FRAMEWORK FOR HOLISTIC GREENING OF VALUE CHAINS
}

\author{
Wei Deng Solvang, Elisabeth Román, Ziqiong Deng, Bjørn Solvang \\ Virtual Manufacturing and Supply Chain Management Research Group, Narvik University \\ College, Lodve Langes gate 2,8505 Narvik,Norway,Email:wds@hin.no
}

\begin{abstract}
Protecting and sustaining nature environment are two of the most important conditions regarding economic and social development. While the resources are extracted from and wastes are disposed to the same mother Earth, managing wastes of a value chain has been segmented and treated isolated. This segmentation leads to the partial optimization in waste minimization. This paper proposes a framework that facilitating holistic greening of a value chain so that total waste minimization can be achieved from entire chain's perspective.
\end{abstract}

Key words: value chain, waste minimization, holistic greening

\section{INTRODUCTION}

Effective waste management and environment protection are essential for the quality of life for current and future generations. Never before have these being more challenged by rapid economic development. The global ecosystem is facing a severe challenge of its economic sub-system as its capacity of energy as well as capability of waste disposal is reaching the limit (Goodland, 1991).

One of the driven forces to this economic development is manufacturing industry. By continuous improvement of material transformation process, a manufacturing system aims to constantly reduce costs and increase valueadded to its products and services. This transformation can usually be viewed in value chains as it often appears as chains of value-added activities.

Please use the following format when citing this chapter:

Solvang, Wei Deng, Roman, Elisabeth, Deng, Ziqiong, Solvang, Bjørn, 2006, in International Federation for Information Processing (IFIP), Volume 207, Knowledge Enterprise: Intelligent Strategies In Product Design, Manufacturing, and Management, eds. K. Wang, Kovacs G., Wozny M., Fang M., (Boston: Springer), pp. 350-355. 
A conventional definition of value is rather as narrow as profit or productivity. However, as current increasingly intensified focus on sustainable development and pressure from government regulation, the connotation of value needs to be refined and extended to embed environmental aspects. Further, as Handfield et al. (1997) declaimed that, in order to be successful with environmentally-friendly practices, environmental management strategies must be integrated into all states of the value chain.

In the recent years, manufacturing industry, being accused as one of the major enemies to environment, has already started with recycling and reusing. Topics cover remanufacturing (Shu \& Flowers, 1999), green disassembly (e.g., Kuo, 2000; Lambert, 2002), cleaner production (Vlavianos-Arvanitis, 1998), reverse logistics (Hirsch et al., 1998), green supply chain management (Handfield et al., 1997), to mention a few. Comparing with the recycle and reuse termed in waste management, the definitions and applications of these two terms in manufacturing industry are rather straight forward in sense that there is only mechanical rather than chemical or biological processes engaged.

Currently, waste management has been treated differently in different knowledge disciplines. The lack of interdisciplinary cooperation and joint venture in integrated waste reduction and minimization leads to local rather than overall optimized waste management. A methodology for enabling overall waste minimization is therefore needed for dealing with following challenges:

- implementing upfront pollution prevention and minimization rather than end-of-pipe pollution control

- eliminating hazardous waste at the source; and

- optimizing overall waste reduction at entire value chain.

The rest of the paper is organized as follows. In section 2 we define a general model of green value chain. Section 3 briefly describes waste management and Environmental Protection Agency (EPA) approaches for pollution prevention and waste management. In Section 4, we propose a framework for holistic greening of value chains. Finally, section 5 provides some concluding remarks and suggestions for future work.

\section{GREEN VALUE CHAIN MANAGEMENT}

Conventionally, a value chain can be defined as the set of activities spanning the entire customer order cycle, including design, procurement, manufacturing and assembly, packaging, logistics, and distribution (Handfield et al., 1997). A green value chain incorporates a new dimension of value into the traditional value chain, namely, environment. As showed in 
Figure 1, the primary material flow which starts from raw material supplier and ends at consumer has been extended to cover a 'from birth to graveyard' perspective. The products that have no utility value will be decomposed or dissembled and the utilizable material/parts go back to the chain. The rest of the products go further to indirect treatment where methods as chemical (i.e., incineration) and biological transformation are applied (Shah, 2000). Examples of outputs of this stage are renewed material and/or energy. The residuals after this stage are transported to landfill and, from there, further transformed to harmless and reusable materials.

However, during each of these value chain stages, wastes are generated in the same processes where value is created and added. These wastes can be hazardous to environment. Among which those end up at landfill are the

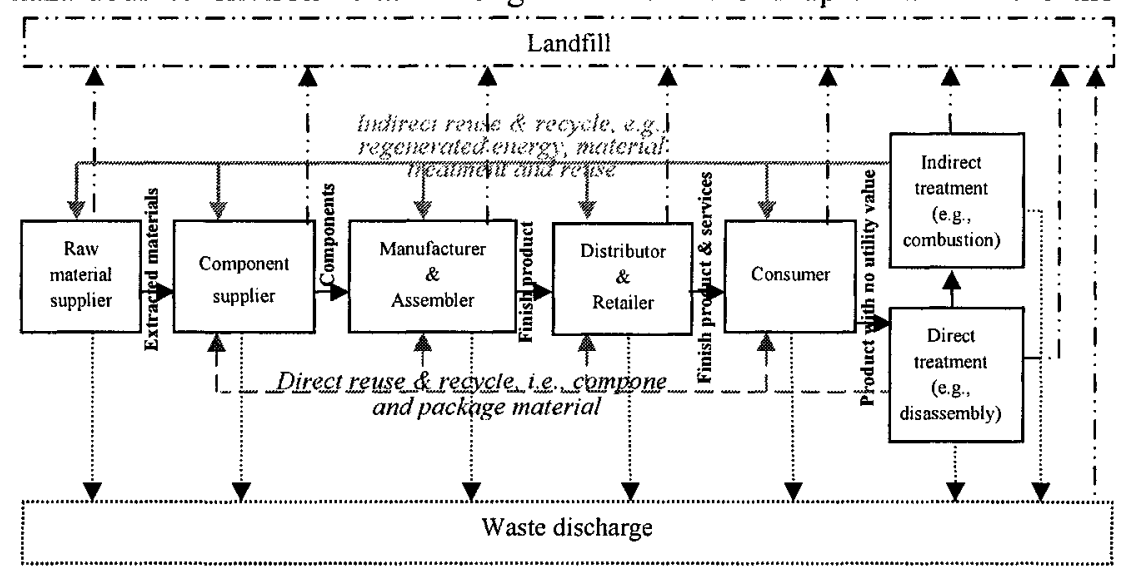

Figure 1. A General Model of Green Value Chain

most hazardous ones. As disposal at landfill is the least preferred form of wastes, efforts should be devoted to minimize total portion (Shah, 2000).

\section{WASTE MANAGEMENT}

Waste management can be generally defined as processes of dealing with waste $\left(\mathrm{DEQ}^{\mathrm{a}}\right)$. It is a sustainable process for reducing the environmental impact of the disposal of all types of materials used by businesses. Over the last decade wastes that end up at landfills are the most hazardous ones (Lagerkvist, 2001). There is a common principle that the pollution from landfills - emissions as gasses and leachate reflects, for example, categories of waste being put into landfills as follows:

${ }^{\text {a }}$ http://www.deq.state.or.us/wmc/solwaste/cwrc/glossary/glossary 1.html 
- Organic waste from households produces gasses as methane, hydrogen and ammonia;

- Plastic material are broken down very slowly;

- Heavy metals and environmental poisons such as dioxine, polyaromatich hydrocarbons (PAH) are dissolved in the leachate. Small concentration can make much harm when coming into contact with ecosystems since they are persistent.

In order to reduce the portion of wastes which ends up at landfill, U.S. Environmental Protection Agency (EPA) has proposed a general hierarchy of recommended approaches to pollution prevention (Figure 2) together with a preferred approach to hazardous waste management (Figure 3).

These approaches to pollution prevention and hazardous waste management stem from the environmental desirability of source reduction as the preferred means of minimizing waste. Recycling techniques allow hazardous materials to be put to a beneficial use and treatment options are considered only after acceptable waste minimization techniques have been identified (Shah, 2000).

To sum up, waste management need to purpose waste minimization that being implemented through following steps:

- source reduction

- resource recovery and recycling

- treatment

- ultimate waste disposal

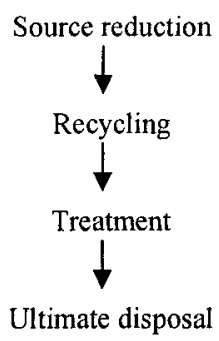

Figure 2. U.S. EPA hierarchy of recommended approaches to pollution prevention

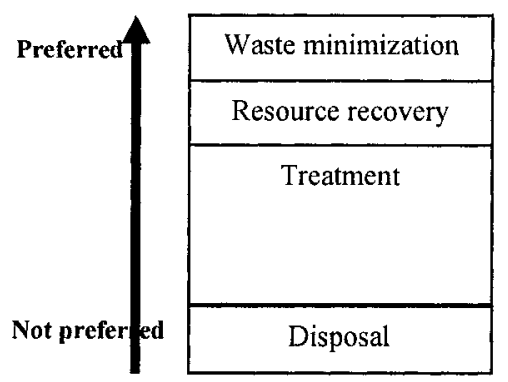

Figure 3. U.S. EPA preferred approach to hazardous waste management 


\section{A FRAMEWORK FOR HOLISTIC GREEN SUPPLY CHAIN MANAGEMENT}

It is stated that there is an urgent need to shift from anthropocentric to biocentric values in society, and to place environmental appreciation at the core of every action and thought (Vlavianos-Arvanitis, 1998). In line with this statement, we propose a framework for holistic greening of value chains as shown in Figure 4.

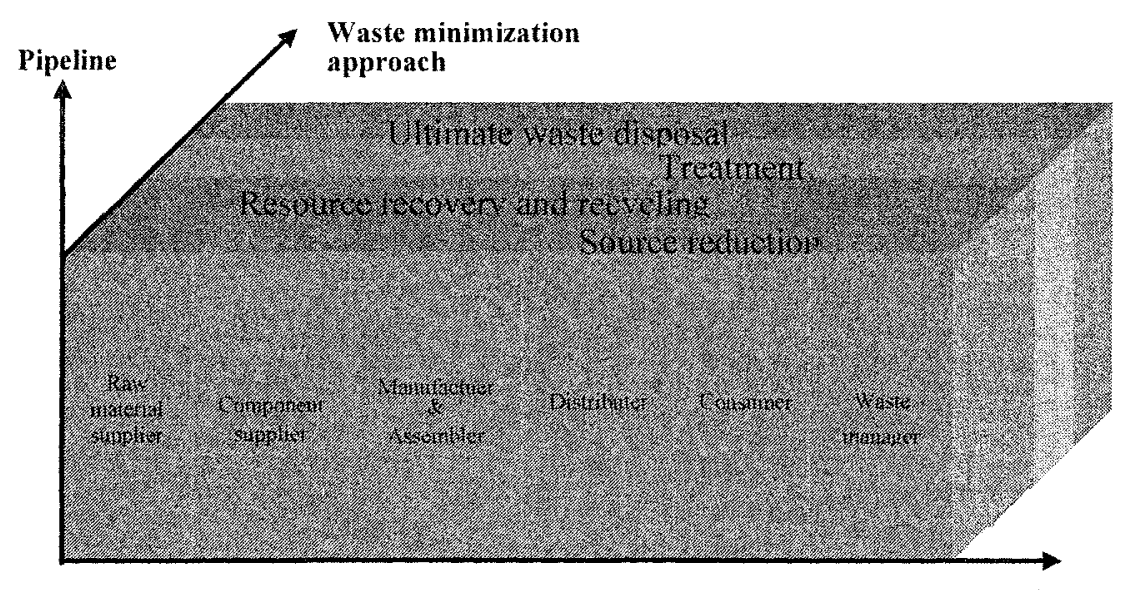

Tier

Figure 4. A Methodological Framework for Holistic Greening of Value Chains

This framework is three-dimensional. The tier dimension categorizes six types of actors corresponding to six stage of a product life cycle. A pipeline within a supply chain refers to the stream of materials, components, and assemblies that are associated with one particular product or tight family of products (Bhaskaran, 1998). While a pipeline illustrates partial horizontal view of a supply chain, a tier represents a vertical segment of the chain. The third dimension categorizes four approaches to achieve waste minimization, namely, source reduction, resource recovery and recycling, treatment, and ultimate waste disposal.

This framework suggests that, no matter where an actor situates or what function it has on its pipeline, it needs to conduct all four approaches at its strategic, tactic, and operational levels in order to achieve holistic greening. This is from an individual actor's perspective. From a pipeline perspective, in order to achieve optimized overall waste minimization, actors in that pipeline needs to coordinate their waste reduction activities in terms of four categories. From waste minimization perspective, our ultimate goal in holistic greening is to minimize the portion of waste (especially hazardous 
waste) which ends up at landfill. This can only be achieved by conducting all four approaches at all actors on all pipelines.

\section{SUMMARY AND FUTURE WORKS}

This paper proposes a methodological framework for achieving holistic greening of value chains. Future research needs to be devoted to model, measure, and evaluate current value chain greening performance.

\section{REFERENCES}

Bhaskaran, S., (1998), Simulation analysis of a manufacturing supply chain, Decision Science 29(3):663-657.

Goodland, R., (1991), Det som taler for at verden har nådd grenser - mer presist at nåværende produksjonsvekst i den globale økonomien ikke kan opprettholdes, in 'Økonomisk Politikk for en Barekraftig Utvikling: oppfolging av Brundtlandkommisjonen', Goodland, R., Daly, H., Serafy, S.E, von Droste, B. ed., J.W. Cappelen Forlag, pp. 1-14.

Handfield, R.B., Waltor, S.V., Seegers, L.K., Melnyk, S.A., (1997), 'Green' value chain practices in the furniture industry, Journal of Operations Management, 15:293-315.

Hirsch, B.E., Kuhlmann, T., Schumacher, J., 1998, Logistics simulation of recycling networks, Compters in Industry, 36:31-38.

Kuo, T.C., (2000), Disassembly sequence and cost analysis for electromechanical products, Robotics and Computer Integrated Manufacturing, 16:43-54.

Lambert, A.J.D., (2002), Determining optimum disassembly sequences in electronic equipment, Computer \& Industrial Engineering, 43:553-575.

Lagerkvist, A., (2001), Landfill Technology, Luleå university of technology, department of environmental engineering, division of waste science \& technology.

Shah, K.L., (2000), Basics of Solid and Hazardous Waste Management Technology, Prentice Hall.

Shu, L.H., Flowers, W.C., (1999), Application of a design-forremanufacturing framework to the selection of product life-cycle fastening and joining methods, Robotics and Computerintegrated Manufacturing, 15:179-190.

Vlavianos-arvanitis, A., (1998), Cleaner production: profit for future generations, Journal of Cleaner Production, 6:381-385. 